\title{
First steps in imaging the right ventricle with iodine-123-metaiodobenzylguanidine (123I-MIBG) and cadmium-zinc-telluride technology
}

\author{
Anisiia Doytchinova, $M D,{ }^{a}$ and Myron Gerson, $M^{a}$ \\ a Division of Cardiovascular Health and Disease, University of Cincinnati Medical Center, \\ Cincinnati
}

Received Apr 2, 2019; accepted Apr 3, 2019

doi: $10.1007 / \mathrm{s} 12350-019-01721-\mathrm{z}$

\section{See related article, pp. 546-556}

Pulmonary hypertension is a physiologic condition defined as mean pulmonary artery pressure (mPAP) $\geq$ $25 \mathrm{~mm} \mathrm{Hg}$ measured on right heart catheterization. This can be caused by a variety of diseases, of which left sided heart dysfunction being the most common. ${ }^{1,2}$ The two large groups of pulmonary hypertension are precapillary, characterized by end-expiratory pulmonary capillary wedge pressure (PCWP) $\leq 15 \mathrm{~mm} \mathrm{Hg}$ and peripheral vascular resistance $>3$ Wood units; and postcapillary, defined as PCWP $>15 \mathrm{~mm} \mathrm{Hg}$. Despite the heterogeneity of conditions leading to elevated pulmonary pressures, pulmonary hypertension uniformly remains an indicator of poor prognosis. The clinical significance of mPAP values between 20 and $24 \mathrm{~mm} \mathrm{Hg}$ remains under debate, with some studies also showing increased mortality in this group. ${ }^{3}$

Pulmonary arterial hypertension (PAH) is a small subset of pre-capillary pulmonary hypertension that occurs in the absence of lung disease, chronic thromboembolism or other rare conditions. ${ }^{4}$ This results from imbalance of secreted vasoactive substances, which favor vasoconstriction, thrombosis, and endothelial and smooth muscle proliferation. ${ }^{5,6}$ Even with the recent therapeutic advances, PAH remains a disease with significant morbidity and mortality. ${ }^{4,7}$ Mortality ranges up to $10 \%$ per year in

Reprint requests: Myron Gerson, MD, Division of Cardiovascular Health and Disease, University of Cincinnati Medical Center, 231 Albert Sabin Way MLC 0542, Cincinnati; gersonml@ucmail.uc.edu J Nucl Cardiol 2021;28:557-9.

1071-3581/\$34.00

Copyright (C) 2019 American Society of Nuclear Cardiology. patients with high-risk indicators such as right ventricular failure, repeated syncope, pericardial effusion, impaired 6minute walk distances, low cardiac index and high levels of B-type natriuretic peptide (BNP), and right atrial pressures. ${ }^{4}$ Because right ventricular failure is the main cause of death in this population, patients with PAH are routinely followed with echocardiography to assess right ventricular function and guide therapy. ${ }^{8}$ However, each echocardiographic measure of right ventricular function has inherent limitations mainly due to the complex shape and structure of the right ventricle. ${ }^{9}$

It is postulated that patients who exhibit a maladaptive pattern of right ventricular remodeling with dilatation, fibrosis, and decreased contractility also demonstrate downregulation of $\alpha, \beta$, and dopaminergic receptors and increased sympathetic activity. ${ }^{10,11}$ As such, nuclear imaging with iodine-123-metaiodobenzylguanidine (123I-MIBG) can potentially play an important role in the management and risk stratification of these patients. In support of this notion, data have suggested that sympathetic function is altered in patients with PAH. In a study of 55 patients with pulmonary hypertension including 28 with $\mathrm{PAH}$, heart-to-mediastinal ratios $(\mathrm{H} / \mathrm{M})$ were lower in pulmonary hypertension compared to control subjects. In addition, $\mathrm{H} / \mathrm{M}$ ratios $>2.0$ were associated with improved survival. $^{12}$ Takao et al. have also shown that right ventricleto-left ventricle $(\mathrm{RV} / \mathrm{LV})$ uptake ratio of $123 \mathrm{I}-\mathrm{MIBG}$ correlates well with mean pulmonary pressures. ${ }^{13}$ More recently in a small study of 21 patients with $\mathrm{PAH}$ and chronic thromboembolic pulmonary hypertension (CTEPH), patients with PAH had lower 123I-MIBG lung uptake compared to subjects with CTEPH and controls. ${ }^{14}$ Contrary to the above findings, clinical studies treating PAH patients with beta blockers have not demonstrated improved outcomes. ${ }^{15}$ It is possible 
that the right dose and/or type of beta blocker has not been tested.

In this issue of the Journal, Gimelli et al. studied 13 patients with newly diagnosed PAH and 11 patients with pulmonary hypertension associated with non-ischemic dilated cardiomyopathy (DCM) using 123I-MIBG uptake and cadmium-zinc-telluride (CZT) technology. The authors employed the 17-segment left ventricle model and scored the percent uptake in the right ventricle relative to the interventricular septum. For this purpose, a semi-quantitative software (Corridor4DM, INVIA; Ann Arbor, MI) was used after manual reconstruction of the right ventricular images. Due to artifacts in the inferior wall, only segments $1,2,3,4,8,9,13$, and 14 were reported and those were designated to correspond to the lateral right ventricular wall. The authors found no difference in H/M ratios between the groups, but noted that patients with PAH had significantly lower lung-to-mediastinal (L/M) ratios. The study also demonstrated that right ventricular perfusion and early innervation were significantly higher in $\mathrm{PAH}$ than in $\mathrm{DCM}$ and that $\mathrm{RV} / \mathrm{LV}$ perfusion and innervation ratios were directly correlated with right ventricular thickness and diameter.

Despite its small size, the study is novel and of potential clinical importance. Lung-to-mediastinal ratios in combination with $\mathrm{H} / \mathrm{M}$ values are associated with all cause mortality and rate of events in patients with heart failure. ${ }^{16,17}$ Previous studies from the authors' group have also shown the feasibility of performing simultaneous LV perfusion and innervation with a CZT camera. ${ }^{18}$ However, this is the first study to apply this concept to the right ventricle.

It is well established that possibly due to prolonged transit time, heart failure and/or elevated left ventricular filling pressure result in increased lung uptake of myocardial perfusion tracers. ${ }^{19}$ This is likely to be an important factor in the increased L/M ratios seen in the DCM patients in the present study as the NT pro-BNP levels averaged $13,213 \mathrm{pg} / \mathrm{mL}$ in the DCM patients and only $259 \mathrm{pg} / \mathrm{mL}$ in the PAH patients. As pulmonary transit time should also be elevated in the PAH patients, this would seem to further support the postulate that low $\mathrm{L} / \mathrm{M}$ ratio in the $\mathrm{PAH}$ patients may reflect impaired pulmonary endothelial function.

The main limitations of the study are the small sample size, significantly higher body mass index in the DCM group, and the poor quality images in some of the cases. There are no prior data applying the 17-segment model of the left ventricle to the right heart. Further, all patients studied had some evidence of right ventricular hypertrophy and it is unknown if such analysis could be performed in those with normal thickness. Given some patients with PAH are diagnosed quite late into their course and there has been no improvement in time to diagnosis over the last two decades, a modality that can aid in earlier diagnosis may be of significant importance. ${ }^{20}$ Additional larger studies are needed to answer these questions, validate the findings presented by the authors, and demonstrate reproducibility.

\section{Disclosure}

The authors have no conflicts of interest to declare.

\section{References}

1. Hoeper MM, Humbert M, Souza R, Idrees M, Kawut SM, SliwaHahnle K, Jing ZC, Gibbs JS. A global view of pulmonary hypertension. Lancet Respir Med. 2016;4:306-22.

2. Hoeper MM, Bogaard HJ, Condliffe R, Frantz R, Khanna D, Kurzyna M, Langleben D, Manes A, Satoh T, Torres F, Wilkins MR, Badesch DB. Definitions and diagnosis of pulmonary hypertension. J Am Coll Cardiol. 2013;62:D42-50.

3. Maron BA, Hess E, Maddox TM, Opotowsky AR, Tedford RJ, Lahm T, Joynt KE, Kass DJ, Stephens T, Stanislawski MA, Swenson ER, Goldstein RH, Leopold JA, Zamanian RT, Elwing JM, Plomondon ME, Grunwald GK, Baron AE, Rumsfeld JS, Choudhary G. Association of borderline pulmonary hypertension with mortality and hospitalization in a large patient cohort: Insights from the veterans affairs clinical assessment, reporting, and tracking program. Circulation. 2016;133:1240-8.

4. Galie N, Humbert M, Vachiery JL, Gibbs S, Lang I, Torbicki A, Simonneau G, Peacock A, Vonk Noordegraaf A, Beghetti M, Ghofrani A, Gomez Sanchez MA, Hansmann G, Klepetko W, Lancellotti P, Matucci M, McDonagh T, Pierard LA, Trindade PT, Zompatori M, Hoeper M and Group ESCSD. 2015 ESC/ERS Guidelines for the diagnosis and treatment of pulmonary hypertension: The joint task force for the diagnosis and treatment of pulmonary hypertension of the European Society of Cardiology (ESC) and the European Respiratory Society (ERS): Endorsed by: Association for European Paediatric and Congenital Cardiology (AEPC), International Society for Heart and Lung Transplantation (ISHLT). Eur Heart J. 2016;37:67-119.

5. Farber HW, Loscalzo J. Pulmonary arterial hypertension. N Engl J Med. 2004;351:1655-65.

6. Lai YC, Potoka KC, Champion HC, Mora AL, Gladwin MT. Pulmonary arterial hypertension: the clinical syndrome. Circ Res. 2014;115:115-30.

7. Humbert M, Sitbon O, Chaouat A, Bertocchi M, Habib G, Gressin V, Yaici A, Weitzenblum E, Cordier JF, Chabot F, Dromer C, Pison C, Reynaud-Gaubert M, Haloun A, Laurent M, Hachulla E, Cottin V, Degano B, Jais X, Montani D, Souza R, Simonneau G. Survival in patients with idiopathic, familial, and anorexigen-associated pulmonary arterial hypertension in the modern management era. Circulation. 2010;122:156-63.

8. van Wolferen SA, Marcus JT, Boonstra A, Marques KM, Bronzwaer JG, Spreeuwenberg MD, Postmus PE, Vonk-Noordegraaf A. Prognostic value of right ventricular mass, volume, and function in idiopathic pulmonary arterial hypertension. Eur Heart $\mathrm{J}$. 2007;28:1250-7.

9. Satriano A, Pournazari P, Hirani N, Helmersen D, Thakrar M, Weatherald J, White JA, Fine NM. Characterization of right ventricular deformation in pulmonary arterial hypertension using 
three-dimensional principal strain analysis. J Am Soc Echocardiogr. 2019;32:385-93.

10. Ryan JJ, Archer SL. The right ventricle in pulmonary arterial hypertension: disorders of metabolism, angiogenesis and adrenergic signaling in right ventricular failure. Circ Res. 2014;115:176-88.

11. Drake JI, Bogaard HJ, Mizuno S, Clifton B, Xie B, Gao Y, Dumur CI, Fawcett P, Voelkel NF, Natarajan R. Molecular signature of a right heart failure program in chronic severe pulmonary hypertension. Am J Respir Cell Mol Biol. 2011;45:1239-47.

12. Sakamaki F, Satoh T, Nagaya N, Kyotani S, Oya H, Nakanishi N, Kuribayashi S, Ishida Y. Correlation between severity of pulmonary arterial hypertension and 123I-metaiodobenzylguanidine left ventricular imaging. J Nucl Med. 2000;41:1127-33.

13. Morimitsu T, Miyahara Y, Sinboku H, Ikeda S, Naito T, Nishijima $\mathrm{K}$, Takao M. Iodine-123-metaiodobenzylguanidine myocardial imaging in patients with right ventricular pressure overload. J Nucl Med. 1996;37:1343-6.

14. Higo K, Kubota K, Miyanaga S, Miyata M, Nakajo M, Jinguji M, Ohishi M. Impairment of iodine-123-metaiodobenzylguanidine ((123)I-MIBG) uptake in patients with pulmonary artery hypertension. Int Heart J. 2018;59:112-9.

15. Perros F, de Man FS, Bogaard HJ, Antigny F, Simonneau G, Bonnet S, Provencher S, Galie N, Humbert M. Use of betablockers in pulmonary hypertension. Circ Heart Fail. 2017;10(4):e003703.
16. Gerson MC, Dwivedi AK, Abdallah M, Shukla R, Jacobson AF. Significance of I-123 metaiodobenzylguanidine ((1)(2)(3)I-MIBG) lung activity in subjects with heart failure in comparison to healthy control subjects. J Nucl Cardiol. 2013;20:592-9.

17. Kamiyoshi Y, Yazaki Y, Urushibata K, Koizumu T, Kasai H, Izawa A, Kinoshita $\mathrm{O}$, Hongo M, Ikeda U. Risk stratification assessed by combined lung and heart iodine- 123 metaiodobenzylguanidine uptake in patients with idiopathic dilated cardiomyopathy. Am J Cardiol. 2008;101:1482-6.

18. Gimelli A, Liga R, Giorgetti A, Genovesi D, Marzullo P. Assessment of myocardial adrenergic innervation with a solidstate dedicated cardiac cadmium-zinc-telluride camera: first clinical experience. Eur Heart J Cardiovasc Imaging. 2014;15:575-85.

19. Boucher CA, Zir LM, Beller GA, Okada RD, McKusick KA, Strauss HW, Pohost GM. Increased lung uptake of thallium-201 during exercise myocardial imaging: clinical, hemodynamic and angiographic implications in patients with coronary artery disease. Am J Cardiol. 1980;46:189-96.

20. Brown LM, Chen H, Halpern S, Taichman D, McGoon MD, Farber HW, Frost AE, Liou TG, Turner M, Feldkircher K, Miller DP, Elliott CG. Delay in recognition of pulmonary arterial hypertension: factors identified from the REVEAL Registry. Chest. 2011;140:19-26.

Publisher's Note Springer Nature remains neutral with regard to jurisdictional claims in published maps and institutional affiliations. 